\title{
DINAR AND DIRHAM; SUSTAINABLE MONEY FOR SUSTAINABLE SOCIETY
}

\author{
Eko Tama Putra Saratian, Harefan Arief, Mochamad Soelton, and Mugiono \\ Universitas Mercu Buana Jakarta, Indonesia \\ Universitas Brawijaya, Indonesia.
}

\begin{abstract}
This is a community service related to the development of economic society through socialization on dinar and dirham as sustainable money. Money in sharia is precious metals such as gold and silver, or commodities such as wheat, barley, dates, and salt, which are the consumed commodities daily as food and have a shelf life. The failure of the current economic and monetary system is caused by the use of fiat money as a medium of exchange that deviates from the gold standard. Ironically, many ordinary people do not understand the real concept of money. In returning the standard of exchange, it is necessary to learn deeply about this subject. For this reason, there is a need for socialization to the wider community to open the way for the return of the dinar and dirham as a true medium of exchange. The results of the activity are expected to increase good understanding of the concept of money and the public can learn to do transaction using dinar and dirham in the future.
\end{abstract}

Keywords: Dinar, Dirham, Fiat Money, Riba, Sustainable Finance

\section{INTRODUCTION}

Nowadays, some people in Indonesia have begun to care about the dangers of riba and its impact on the economy. Muslims have believed that riba is haram. Some of them certainly can define as well as interpret the term of riba. Money in sharia is precious metals such as gold and silver, or commodities such as wheat, barley, dates, and salt, which are the consumed commodities daily as food and have a shelf life. The failure of the current economic and monetary system is caused by the use of fiat money as a medium of exchange that deviates from the gold standard. Ironically, many ordinary people do not understand the real concept of money. According to Prasetyo (2017), the main function of money is as a medium of exchange, but the capitalist economic system views the function of money as a commodity and becomes an object of trade.

The economic crisis that shook Southeast Asia in 1997-1998, the United States in 2008, and several countries in 2013, made economists, especially those from Islam, look for solutive exchange media besides fiat money. The crisis is a valuable lesson because it provides awareness about the weaknesses of fiat money and shows that the monetary regime with US Dollar standards is very unfair, hegemonic and fragile. Malaysian Prime Minister, Mahathir Muhammad, clearly expressed his interest in currency unification using gold dinars (Hasan, 2017). Mahathir not only understood and understood the exploitative nature of the monetary system created by Western civilization, so Mahathir called for a return to the use of the gold standard as money.

The monetary system using fiat money and dependence on the US Dollar is a falsehood so that exiting the system is an escape from economic oppression and financial exploitation (Hosein, 2007). Because if the gold standard is reached, almost all modern economic diseases such as rampant inflation, ups and downs in credit, stagnation, unemployment will be solved (Cizakca, 2010). According to Marlia (2014), inflation is generally caused by the printing of money by monetary authorities that exceeds economic needs so that the amount of money in circulation in the economy increases. The problem of currencies (including dinars and dirhams) is not just a matter of injustice, inequality, stability or religious indicators, more than that it is a political, social problem and so on. For example the riba currency with the fiat money system has taken root and is ingrained for humanity, because from birth to large they have been served with the fiat money system, therefore it is very difficult to be separated from the system (Hasan, 2017).

Islam has arranged all things, including in the activities of human muamalah, one of which is the issue of medium of exchange.

From Abu Said al-Khudri, that the Prophet Muhammad Shallallaahu 'Alaihi Wasallam said Bilal came to the Prophet with a date, and when he asked him where he got it from, he replied: I have a low quality date and then I exchange two bushels of dates with one bushel (this date). The Prophet Shallallaahu 'Alaihi Wasallam responded: Ah! This is the essence of Riba, the essence of Riba! Do not do this. If you want to buy, sell the dates in a separate transaction, then buy these dates with what you get, from the sale (HR. Bukhari Muslim). 
Prophet Muhammad Shallallahu 'Alaihi Wasallam forbade an unbalanced exchange between dates and dates. He stated that the exchange was the essence of Riba. The essence of money in Islam as stated by the Prophet Muhammad Shallallaahu 'Alaihi Wasallam namely from Abu Said al-Khudri,

Gold with gold, silver with silver, wheat with wheat, barley with barley, dates with dates, and salt with salt. (If the transaction) likes and likes, payment is made on the spot, then if someone gives more or asks for more, he does Riba, the recipient and the giver are equally guilty (HR. Muslim).

Some people argue, at this time of course the public is allowed to accept a paper system that is not redeemable, which is easily printed by the central bank and determines a fictitious value on it, and in the process becomes a pseudo wealth creator. This certainly becomes interesting to be socialized to ordinary people who do not understand the concept of money as a medium of exchange.

\section{LITERATURE REVIEW}

According to Alhifni dan Trihantana (2016), money is a tool that used as a means of payment in the transaction. In the Islamic concept of money is a means to transact and exchange tool. Seigniorage is the difference between the intrinsic value and the nominal value of money. Dinar currency is the currency used by several countries in the form of gold used since the seventh century BC. Dinar eligible to be used as a means of transaction for two coins have a value and a stable element, while the Dirham is derived from the language of the people Sassan in Persian is "drachms".

According to Surahman (2016), money is a standard of utility (utility) contained in an item and service. For this reason, money is defined as something that is used to measure individual goods and services. History records that the dinar and dirham were used as official currencies during the time of the Prophet Shallallaahu 'Alaihi Wasallam, al-Khulafa ar-Rashidin and Islamic dynasties until the collapse of the Ottoman Turks in 1923. During that time, the use of gold was very stable and did not experience inflation that was stable. means it. In contrast to fiat money which is vulnerable to inflation and economic fluctuations and influenced by politics. Fiat money is a currency system that is considered not to represent the interests of the world because it is contrary to the laws of production and distribution that are vulnerable to riba and tyranny. Therefore, the use of fiat money as a medium of exchange must be replaced by a more fair and balanced media exchange that is far from injustice (Hasan, 2017).

Allah Subhanahu Wa Ta'ala shows the Dinar in the following verse of Surah Ali Imran:

"Among the scribes (Taurat) there are people who if you entrust him with a lot of wealth, are returned to you; and among them there are those who, if you entrust him with a Dinar (gold coin), do not return it to you, unless you always collect it. That is (double standard) because they say, "There is no sin for us against the ummi (Arabs)." They say lies against Allah, even though they know" (Al-Qur'an, Ali Imran, $3: 75$ )

Allah Subhanahu Wa Ta'ala also shows the Dirham in the verse in Surah Yusuf:

And they sell him (Yusuf) at a cheap price, which is only a few Dirhams, and their hearts do not feel attracted to him. (Al-Qur'an, Joseph, 12 : 20). In both verses of the Qur'an, Allah Subhanahu Wa Ta'ala has shown money as Dinar and Dirham. Dinar is a gold coin that has intrinsic value, and Dirham or silver coins also have intrinsic value. Clearly, both are material created by God and both have values determined by Him who are the creators of sustenance.

There are also other verses in the Qur'an that show gold and silver as treasures and can be used as money in the form of Dinars and Dirhams, this is clearly the context of using gold and silver as money.

"Made beautiful in (the sight of) people in love with what is desired, namely women, children, many treasures of gold, silver, selected horses, livestock, and rice fields. That is the pleasure of living in the world; and with Allah is a far better place (Paradise)" (Al-Qur'an, Ali Imran, 3 : 14). "............... And those who keep gold and silver and not spend it in the way of Allah, tell them (that they will get) a painful punishment" (Al-Qur'an, At-Taubah, $9: 34)$. 
Al-Qur'an then reported that gold and silver will be maintained status as objects with valuable value until the hereafter. In other words, gold and silver have spiritual realities as valuable things, which are in addition to their material value in the world:

"They wear fine green silk clothes embroidered with gold and thick silk and are attached to them bracelets made of silver, and God gives to they are clean drinks. "[This verse, also the following verses declare that gold and silver remain valuable and valuable even in the afterlife] (Al-Qur'an, Al-Insan, 76 : 21).

"Why not put a gold bracelet or an angel to come with him to accompany him" (Al-Qur'an, az-Zukhruf, 43 :53).

"Circulate to them the plates of gold, and the trophies and in that paradise there is everything that is desired by the heart and is pleasing (to the eye) and you are eternal in it" (Qur'an, Az-Zukhruf, 43 : 71 ).

"(For them) Paradise 'Adn, they entered into it, in which they were given jewelery with gold bracelets, and with pearls, and their clothing in them was silk" (Al-Qur'an, Fathir, 35 : 33).

"Verily, Allah puts the believers and works of righteous deeds into the heavens beneath which rivers flow. In heaven they were given jewelry with gold and pearl bracelets, and their clothes were silk" (Al-Qur'an, Al-Hajj, 22 : 23).

"These are they (those who) for them Heaven" Adn, flowing rivers beneath them; in heaven they were adorned with gold bracelets and they wore green garments of fine silk and thick silk while they sat leaning on beautiful couches. That is the best return, and a beautiful resting place" (Al-Qur'an, Al-Kahf, 18: 31).

In fact, Dinar plays an important role on Judgment Day itself. In a hadith, the weight of goodness in the heart when measured by Dinar will be a measure that can get people out of hellfire. Abu Said al-Khudri reported: On Judgment Day a mua'dzin announced:

"Let everyone follow what they used to worship ..." Then they will be saved from fire; and they will take large numbers of people who have been burned by fire to the calf bones or knees. Then they said: "O our Lord, there are no more people who are according to what you commanded us to remain in (Hell)". Then He said: "Return and bring (from the fires of hell) those who in your heart find goodness worth one Dinar." Then they will take a large number of people. Then they will say: "O our Lord! We did not leave anyone who was according to what You commanded us. "Then He said:" Go back and bring those who in their hearts you find goodness worth half a Dinar. "Then they will take a large number of people, and will say:" O our Lord! There will no longer be any one according to what Thou commanded us to remain in. "Then He will say:" Come back and those whom you find goodness in his heart the goodness of one particle, bring it out. "They will take a large number of people, and then said: "O our Lord, now we leave no one in it (hell) to have good ..." (HR. Muslim).

\section{METHOD}

In this Community Service, the methods used are interactive lectures, discussion and question and answer. This lecture was packaged as a socialization activity held on March 14th, 2019 at $09.00-12.00$ at the RPTRA Kampung Baru, Jalan Teratai Kampung Baru RT. 009/010, Kelurahan, Kembangan Utara, Kecamatan Kembangan, Jakarta Barat, DKI Jakarta. This activity was attended by around of 50 students from Al-Washilah 1 Jakarta Vocational School.

The purpose of this activity is to provide socialization and further assistance for transactions using the dinar and dirham in North Kembangan, Kembangan, West Jakarta. In addition, the objectives of this activity include: (a) increasing public understanding of the principles of muamalah and the sharia economic system, (b) understanding the prohibitions and negative impacts of riba on the economy, (c) providing an introduction to Islamic financial instruments as a solution in financial management family.

\section{RESULT AND DISCUSSION}

The evidence from the Qur'an and the Hadith mentioned above shows that gold and silver were created by Allah Subhanahu Wa Ta'ala with the value bestowed on him and that value will last in the life of this world and even persevere in the hereafter. These propositions also show that God, by His wisdom, created gold and silver to be used, one of which was money. According to Ilyas (2016), the function of money can be divided into two, namely the original function and the derivative function. There are three kinds of genuine functions in money, the first as a medium of exchange, the second as a unit of calculation, and the third as a store of value. Whereas the derivative function of money is, first, money as a legal payment tool, second money as a means of debt 
payment, third money as a means of wealth saving, fourth money as a means of transferring wealth, and fifth money as a means of driving economic activity.

Money with intrinsic value has now disappeared from the financial system used throughout the world. We are also guilty of leaving money that is based on the proposition and even worth it in the afterlife. At present, the community has experienced terrible economic difficulties because of leaving the dinar and dirham, and accepting the exchange with an uncertain exchange, namely paper money.

Prophet Muhammad Shallallaahu "Alaihi Wasallam said "there will come a time in mankind, at that time a person who does not have white (silver) and yellow (gold), he will be troubled in life" (HR. At-Thabrani). In addition, the Prophet Shallallaahu "Alaihi Wasallam said "there will come a time to mankind, at that time there will be nothing useful except dinars (gold coins) and dirhams (silver coins)" (HR. Ahmad). Then he Shallallaahu "Alaihi Wasallam also said "If at the end of time, humans among them must use dirhams and dinars so that with both currencies a man upholds his religion and world" (HR. At-Thabrani).

\section{CONCLUSION}

The hadith of the Prophet Muhammad Shallallaahu a Alaihi Wasallam which forbids unequal exchange between dates and dates explains three things; First, stating that money is a precious metal such as gold and silver, or commodities such as wheat, barley, dates, and salt which are commodities that are consumed daily as food and have a shelf life. Therefore, when there is a scarcity of gold and silver coins on the market in Madina, commodities such as dates that are available in the market in large quantities and have a saving time are used as money. Second, when gold, silver, wheat, barley, dates, and salt, (rice, sugar, etc.) are used as money, the value of money is "inside" the money and not "outside". Therefore, 'money' should have intrinsic value. Third, money is always in the creation of Allah Subhanahu Wa Ta'ala in the commodity created and with the value determined by Him too. Allah Subhanahu Wa Ta'ala revealed Himself as Ar-Razzaq, creator of wealth. We can conclude that money according to the Sharia is as follows; (a) precious metals or other commodities as described above, (b) money with intrinsic value, (c) money is in Allah's creation with a value determined by Allah Subhanahu Wa Ta'ala who creates wealth.

Based on the discussion in the previous chapters, it can be concluded that this socialization is expected to increase public knowledge, including: (a) the realization of an increase in public understanding of the Muamalah Principles and Sharia Economic System, (b) the realization of an understanding of the prohibition and the negative impact of riba on the economy, (c) the realization of the introduction of the dinar and dirham as a solution in the medium of exchange and financial transactions. From Abu Said al-Khudri, that the Prophet Shallallaahu "Alaihi Wasallam said: "Whoever sees (whatever is) munkar, then change it with his hands; and if he is unable to do so, then with his tongue; and if he is unable to do so, then with his heart; and that is the weakest faith" (HR. Muslim).

\section{REFERENCES}

A. Alhifni dan R. Trihantana. (2016). "Impact Analysis of The Use of Dinar in Monetary Transactions". Jurnal Syarikah 2. Vol. 2, 267-278.

Al-Qur'an, Al-Karim.

Cizakca, Murat. (2010). “The Case Against the Islamic Gold Dinar”. MPRA Paper, No. 26645.

Hadits Bukhari, Muslim, Ahmad, At-Thabrani.

Hasan, Asyari. (2017). "Dilema Penerapan Emas (Dinar) sebagai Mata Uang Internasional: Studi atas Politik Moneter Dunia”. Jurnal Ilmu Syari'ah dan Hukum. Vol. 51, No. 2, 423-444.

Hosein, Imrān N. (2007), The Gold Dinar and Silver Dirham: Islam and the Future of Money. San Fernando: Masjid Jami'ah.

Ilyas, Rahmat. (2016), “Konsep Uang dalam Perspektif Ekonomi Islam”. Jurnal Bisnis dan Manajemen Islam. Vol. 4, No. 1, 35-57.

Marlia. (2014), “Stabilitas Dinar Emas dan Nilai Tukar Rupiah terhadap Inflasi di Indonesia”. Jurnal Ekonomi Pembangunan. Vol. 12, No. 1, 12-28.

Presetyo, Aji. (2017), “Peran Uang dalam Sistem Moneter Islam”. Majalah Ekonomi. Vol. XXII, No. 1, 104110. 
Soelton, Mochamad, Nugrahati, Tati, (2018). How Complaining Behaviors Effect on Coping Stress and Anxiety?. International Journal of Saudi Journal of Business and Management Studies (SJBMS). Vol. 3, No. 6. 623-628.

Soelton et al, (2019). Gender : Stress Levels On Performance In Modern Industry. International Journal Archives of Business Research (United Kingdom). Vol. 7, No 2. 72-81

Soelton et al, (2018). Toward The Best Strategy In Minimizing The Spread of Drug Users. International Conference On Community Development In Asia. Vol 1. No 1. 171-176 